\title{
Analisis Pendapatan Usahatani Tumpangsari Palawija di Desa Letneo Selatan dan Desa Unini Kecamatan Insana Barat
}

Egidius Sanit $^{\mathrm{a}}$, dan Agustinus Nubatonis ${ }^{\mathrm{b}}$

${ }^{a}$ Fakultas Pertanian, Universitas Timor, Kefamenanu, TTU - NTT, Indonesia.

${ }^{b}$ Fakultas Pertanian, Universitas Timor, Kefamenanu, TTU - NTT, Indonesia.

\section{Article Info}

Article history:

Received 16 Januari 2018

Received in revised form 5 Maret 2018

Accepted 28 Maret 2018

\section{Keywords:}

Pendapatan Usahatani

Tumpangsari

Palawija

Letneo Selatan

Unini

\section{Abstrak}

Desa Letneo Selatan dan desa Unini adalah dua desa yang terletak di dataran kaki gunung Basamtasa kecamatan Insana Barat yang masyarakatnya menjalankan usahatani palawija dengan pola tanam tumpangsari. Komoditi palawija yang ditanam adalah jagung lokal putih, jagung lokal kuning, kacang tanah, kacang hijau dan ubi kayu. Tujuan penelitian ini adalah untuk mengetahui 1) gambaran umum usahatani palawija; dan 2) pendapatan usahatani palawija di desa Letneo Selatan dan desa Unini, kecamatan Insana Barat, kabupaten TTU yang dilaksanakan di desa Letneo Selatan dan Desa Unini, kecamatan Insana Barat, Kabupaten TTU, pada bulan Agustus sampai Desembe 2017. Penentuan sampel dilakukan dengan metode purposive samling dengan kriteria memiliki luas lahan $>40$ are dan menggunakan pola tanam tumpangsari, sehingga sampel yang digunakan adalah sebanyak 30 orang. Untuk mengetahui gambaran umum usahatani palawija maka digunakan metode analisis deskriptif kualitatif sedangkan mengetahui pendapatan usahatani palawija maka dilakukan analisis pendapatan. Hasil penelitian menunjukkan usahatani palawija di desa Letneo Selatan dan desa Unini, kecamatan Insana Barat dilakukan dengan pola tanam tumpangsari tanaman jagung lokal putih, jagung lokal kuning, kacang tanah, kacang hijau dan ubi kayu. Terdapat juga kacang tali yang tidak dianalisis dalam penelitian ini. Tahap-tahap usahatani yang dilakukan meliputi persiapan lahan, persiapan benih, penanaman, penyulaman, penyiangan atau penyemprotan pestisida, panen dan pasca panen. Selama melakukan usahatani, petani mengeluarkan total biaya sebesar Rp33.565.625,00 dengan rata-rata biaya Rp1.118.854,17 yang terdiri dari biaya tetap dan biaya variabel Total penerimaan usahatani palawija dalam satu kali musim tanam sebesar Rp232.895.000,00 dengan rata-rata penerimaan setiap petan sebesar Rp7.763.167,00 sehingga petani memperoleh total pendapatan Rp.199.329.375,00 dengan rata-rata pendapatan setiap petani sebesar Rp6.644.312,50 dengan perincian pendapatan dari jagung lokal putih sebesar Rp2.342.029,17, dari jagung lokal kuning sebesar Rp1.539.529,17, dari kacang tanah sebesar Rp309.029,17, dari kacang hijau sebesar Rp261.195,83, dan dari ubi kayu sebesar Rp2.192.529,17. (C2018 dipublikasikan oleh Agrimor.

\section{Pendahuluan}

Masyarakat di pulau Timor umumnya melakukan usahatani dengan pola tumpangsari. Ceunfin $d k k$., (2018) menyatakan masyarakat di pulau Timor terbiasa dengan melakukan sistem tanam tumpangsari sebagai bentuk penanggulangan terhadap kekurangan air di akhir musim hujan. Menurut Karyawati $d k k$., (2010) tumpangsari adalah penanaman dua atau lebih jenis tanaman secara berdekatan pada lahan yang sama dan terdapat interaksi di antara tanaman tersebut dan menurut Ceunfin $d k k$., (2017) menanam lebih dari satu tanaman semusim yang berbeda namun saling memberi keuntungan dapat dilakukan untuk mengurangi input sumberdaya.

Beberapa keuntungan pada pola tumpangsari antara lain: 1) akan terjadi peningkatan efisiensi (tenaga kerja, pemanfaatan lahan maupun penyerapan sina matahari), 2) populasi tanaman dapat diatur sesuai yang dikehendaki, 3) dalam satu areal diperoleh produksi lebih dari satu komoditas, 4) tetap mempunyai peluang mendapatkan hasil manakala satu jenis tanaman yang diusahakan gagal dan 5) kombinasi beberapa jenis tanaman dapat menciptakan stabilitas biologis sehingga dapat menekan serangan hama dan penyakit serta mempertahankan kelestarian sumber daya lahan dalam hal ini kesuburan tanah (Warsawa, 2009).

Tumpangsari telah dilakukan masyarakat kabupaten Timor Tengah Utara secara turun temurun. Menurut Ceunfin $d k k$., (2018) sistem tumpangsari yang dilakukan di pulau Timor khususnya kabupaten TTU masih sangat tradisional yaitu dengan menanam beberapa jenis tanaman yang berbeda spesies dalam lubang tanam yang sama. Neo \& Ceunfin, (2018) menambahkan bahwa tumpangsari biasa dilakukan pada tanaman palawija seperti jagung, kacang kacangan dan ubi-ubian.

Istilah palawija merupakan istilah yang berasal dari petani di pedesaan pulau Jawa terutama Jawa Tengah yang berarti tanaman selain padi. Istilah in kemudian menyebar luas dan sudah menjadi istilah umum dalam bidang pertanian lahan kering. Palawija dapat dikelompokkan menjadi tiga jenis yaitu 1) Pala Gumatung untuk penyebutan tanaman palawija yang buahnya berada menggantung di batang pohon dan jauh dari permukaan tanah misalnya jagung, centel, sorgum, kedelai, kacang hijau dan sejenisnya; 2) Pala Kesimbar untuk penyebutan tanaman yang buahnya tergeletak di atas permukaan tanah misalnya labu, semangka, garbis dan sejenisnya; dan 3) Pala Kependhem untuk penyebutan tanaman yang buahnya berada di dalam tanah seperti ubi kayu, kentang, bawang, wortel, ubi jalar dan sejenisnya. Ada juga jenis pala lain yakn Pala Kirna yakni untuk penyebutan tanaman buah-buahan dan sayuran (Suparman, 2007)

Produktivitas berbagai komoditi palawija di kabupaten TTU seperti jagung, kacang tanah, kacang hijau dan ubi kayu cukup tinggi berdasarkan beberapa hasi penelitian terdahulu seperti jagung dapat mencapai produktivitas $3,178 \mathrm{t} / \mathrm{ha}$ (Manikin \& Lelang, 2016) dan 3,48 t/ha (Bhato, 2016), kacang tanah dengan produktivitas 3,7 t/ha polong kering (Berek $d k k$., 2017), kacang hijau dengan produktivitas 1,07 t/ha (Neonbeni \& Seran, 2017).

Desa Letneo Selatan dan desa Unini adalah dua desa yang terletak di dataran kaki gunung Basamtasa kecamatan Insana Barat yang masyarakatnya menjalankan usahatani palawija dengan pola tanam tumpangsari. Komodit palawija yang ditanam adalah jagung lokal putih, jagung lokal kuning, kacang tanah, kacang hijau dan ubi kayu. Sebagian besar petani memiliki lahan lebih dari satu bidang dan membudidayakan tanaman secara acak tanpa mengatur jarak tanam dengan tanaman utama adalah jagung lokal. Hal ini dilakukan untuk menjaga kestabilan produksi, ketika salah satu tanaman gagal atau produksinya kurang, tanaman yang lain bisa mengganti untuk memenuhi kebutuhan.
Jagung yang ditanam adalah jagung lokal kuning (pena molo) dan jagung lokal putih (pena muti) yang merupakan tanaman yang sudah dibudidayakan secara turun temurun. Jagung lokal memiliki keunggulan yakni bertahan lama bila disimpan dan tidak mudah terkena hama. Hasil panen jagung lokal tidak semuanya dipasarkan, hal ini dikarenakan umumnya jagung masih merupakan makanan pokok masyarakat. Jagung lokal yang sering dikonsumsi adalah jagung putih, sedangkan jagung kuning untuk dijual. Menurut laporan Falo \& Fallo, (2016) jagung lokal kuning di kecamatan Insana Barat juga digunakan sebagai bahan baku agroindustri tortila atau kerupuk jagung.

Hasil kacang tanah dan kacang hijau juga sebagian digunakan untuk memenuhi kebutuhan konsumsi dan sisanya baru dijual. Umumnya, setelah panen masyarakat tidak langsung memasarkannya, hal ini dikarenakan harga jual pada masa panen raya yang relatif murah, sehingga pemasaran tergantung pada kebutuhan. Sebagian masyarakat memasarkannya hanya apabila terdapa kebutuhan mendadak. Khusus untuk ubi kayu, masyarakat hanya melakukan panen saat akan dikonsumsi atau akan dijual. Jika ditinjau dari aspek ekonominya maka dapat dikatakan petani di desa Letneo Selatan dan desa Unini masih menerapkan pertanian subsistem yakni pertanian yang belum berorientasi pasar dan hasil lebih diarahkan atau digunakan untuk kebutuhan konsumsi dan hanya sedikit atau sebagian yang dipasarkan. Model pertanian subsistem biasanya kurang berperan dalam meningkatkan kesejahteraan petani dan masyarakat, padahal menurut Falo \& Nubatonis, (2017) pembangunan pertanian ke depan diharapkan dapat memberikan kontribusi yang lebih besar serta mampu memanfaatkan peluang ekonomi. Beberapa penelitian terdahulu juga telah melaporkan bahwa komoditi palawija dapat memberikan keuntungan atau pendapatan bagi petani, misalnya laporan Nahak \& Kune, (2017) bahwa usahatani jagung di desa Bannae, kecamatan Insana Barat menguntungkan secara ekonomis dan memperoleh pendapatan setiap petani hingga sebesar Rp1.148.837,00. Laporan Tetik \& Fallo, (2016) juga menjelaskan bahwa usahatani kacang hijau di kecamatan Wewiku kabupaten Malaka menguntungkan secara ekonomis dan memperoleh pendapatan setiap petani hingga sebesar Rp1.493.494,00.

Menurut Haryanto, (2007) agar suatu usahatani tidak rugi maka harus diketahui terlebih dahulu analisis usahataninya. Suratiyah, (2006) juga menyatakan bahwa dengan memahami data-data usahatani maka petani dapa merencanakan produksi sesuai dengan pendapatan yang diinginkan. Oleh karena itu, perlu dilakukan penelitian dengan topik "Analisis Pendapatan Usahatan Tumpangsari Palawija di Desa Letneo Selatan dan Desa Unini Kecamatan Insana Barat". Tujuan penelitian ini adalah untuk mengetahui 1) gambaran umum usahatani palawija; dan 2) pendapatan usahatani palawija di desa Letneo Selatan dan desa Unini, kecamatan Insana Barat, kabupaten TTU.

\section{Metode}

Penelitian dilaksanakan di desa Letneo Selatan dan Desa Unini, kecamatan Insana Barat, Kabupaten TTU, pada bulan Agustus sampai Desember 2017. Populasi dalam penelitian ini adalah semua petani di desa Letneo Selatan dan desa Unini, kecamatan Insana Barat yang mengusahakan tanaman palawija yang berjumlah 200 orang. Penentuan sampel dilakukan dengan metode purposive samling sesuai petunjuk Ating \& Sambas, (2006) dengan kriteria memiliki lua lahan >40 are dan menggunakan pola tanam tumpangsari jagung lokal dengan ubi kayu, kacang tanah dan kacang hijau, sehingga sampel yang digunakan adalah sebanyak 30 orang. 
Data yang digunakan dalam penelitian ini adalah data primer yang diperoleh dengan teknik wawancara langsung dengan responden atau petani yang berusahatani palawija di lokasi penelitian sedangkan data sekunder diperoleh dari instansi atau lembaga terkait.

Data yang diperoleh dikumpulkan kemudian ditabulasi dan dianalisis berdasarkan tujuan penelitian. Untuk mengetahui gambaran umum usahatani palawija maka digunakan metode analisis deskriptif kualitatif sesuai petunjuk Sugiyono, (2006), sedangkan mengetahui pendapatan usahatani palawija maka dilakukan analisis pendapatan sesuai petunjuk Soekartawi, (1995), dengan formula:

$$
\begin{aligned}
& \mathrm{Pd}=\mathrm{TR}-\mathrm{TC} \\
& \mathrm{TR}=\mathrm{Py} . \mathrm{Y}
\end{aligned}
$$

$\mathrm{TC}=\mathrm{FRC}+\mathrm{VC}$

Sehingga $\mathrm{Pd}=\{[\mathrm{Py} . \mathrm{Y}] /[\mathrm{FC}+\mathrm{VC}]\}$ dimana:

$\mathrm{Pd}=$ Pendapatan usahatani palawija

Py = Harga (jagung, ubi kayu, kacang tanah, dan kacang hijau)

$\mathrm{Y}$ = Produksi yang diperoleh (jagung, ubi kayu, kacang tanah, dan kacang hijau)

$\mathrm{FC}=$ Biaya tetap

$\mathrm{VC}=$ Biaya variabel

Biaya produksi yang dikeluarkan oleh petani dihitung sesuai petunjuk Hadisapoetro, (1973).

\section{Hasil dan Pembahasan}

\subsection{Karakteristik Petani Responden}

Umur merupakan salah satu faktor yang mempengaruhi tingkat kemampuan petani dalam mengelola usahataninya karena umur mempengaruhi kemampuan fisik untuk bekerja dalam melakukan usahataninya. Umur responden berkisar antara 35-65 tahun dengan distribusi dalam kelompok umur dapat dilihat pada Gambar 1. dimana dapat diketahui bahwa $50 \%$ petani memiliki umur dalam kisaran 46-55 tahun.

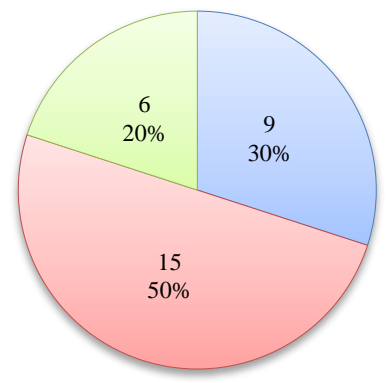

$\square 35-45$ Tahun $\square 46-55$ Tahun $\square 56-65$ Tahun

Gambar 1. Umur Petani Palawija di Desa Letneo Selatan dan Desa Unini

Selain umur, pendidikan juga dapat menjadi salah satu faktor pembentukan pola pikir seorang petani dalam mengelola usahataninya. Petani palawija di desa Letneo Selatan dan desa Unini berpendidikan SD, SLTP hingga SMA dengan jumlah dan persentase yang dapat dilihat pada Gambar 2. dimana dapat diketahui bahwa lebih banyak atau $40 \%$ petani berpendidikan SD.

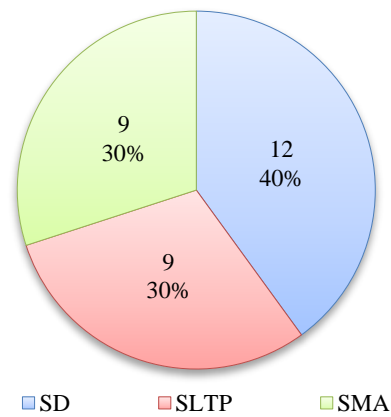

Gambar 2. Tingkat Pendidikan Petani Palawija di Desa Letneo Selatan dan Desa Unini

Jumlah tanggungan keluarga petani palawija di desa Letneo Selatan dan desa Unini berkisar antara 2-9 orang seperti pada Gambar 3. dimana paling banyak atau $50 \%$ petani menanggung 2-3 orang keluarganya.

Pengalaman petani dalam melakukan usahatani palawija berkisar antara 525 tahun seperti pada Gambar 4. Ketidakpastian datangnya musim hujan dan meningkatnya kejadian angin kencang menjadikan pengalaman petani sebagai hal penting dan cukup menentukan keberhasilan usahatani yang dilakukan.

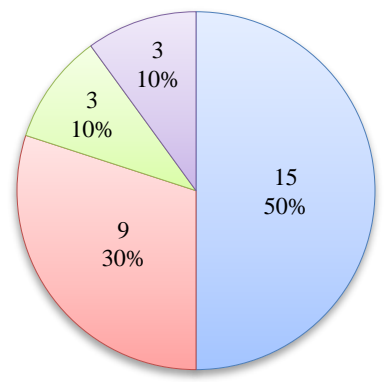

$\square$ 2-3 Orang $\square$ 4-5 Orang $\square$ 6-7 Orang $\square>7$ Orang

Gambar 3. Jumlah Tanggungan Keluarga Petani Palawija di Desa Letneo Selatan dan Desa Unini

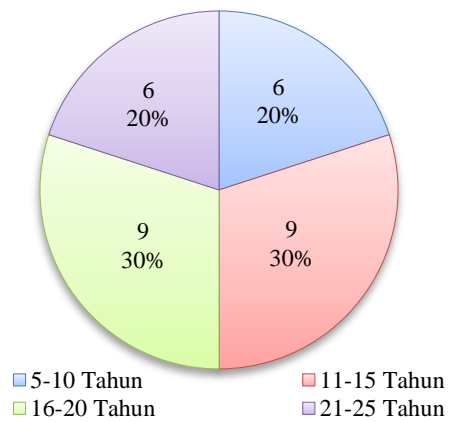

Gambar 4. Pengalaman Berusahatani Petani Palawija di Desa Letneo Selatan dan Desa Unini

\subsection{Gambaran Usahatani Palawija}

Petani responden di wilayah dataran di bawah gunung Basamtasa menjalankan usahatani dengan pola tanam tumpangsari tanaman jagung lokal putih, jagung lokal kuning, ubi kayu, kacang tanah, dan kacang hijau. Tahapan kegiatan yang dilakukan dalam berusahatani adalah persiapan lahan dan pengolahan lahan, persiapan bahan tanaman, penanaman, penyiangan, panen dan pasca panen. Budidaya jagung yang dilakukan oleh petani di daerah tersebut pada awal musim hujan.

a. Persiapan Lahan

Lahan yang digunakan oleh petani adalah lahan milik sendiri dengan luas lahan berkisar antara 75-206 are dengan, paling banyak petani memiliki lahan seluas 130-140 are yakni sebanyak 9 orang atau 30\%. Variasi luas lahan dapat di lihat pada Gambar 5.

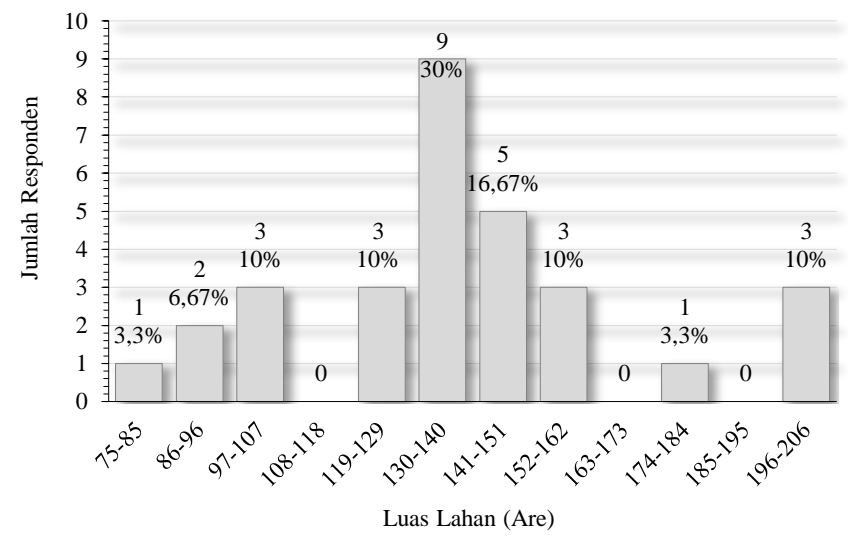

Gambar 5. Luas Kepemilikan Lahan

Lahan dipersiapkan sebelum hujan pada musim kemarau mulai dari bulan Juli sampai akhir bulan Oktober. Alat yang digunakan saat persiapan lahan yaitu parang, sabit dan linggis. Persiapan lahan secara sistem tebas bakar, sehingga setelah tebas tumbuhan liar yang tumbuh di lahan dikumpulkan dan dibiarkan sampai kering lalu dibakar sampai bersih. Setelah itu lahan siap digunakan. Tetapi ada juga petani yang setelah pembakaran masih dilanjutkan lagi dengan pengolahan lahan dengan menggunakan linggis. Fungsi masing-masing alat yang dipakai yaitu parang dipakai untuk tebas pohon-pohon kecil, sabit dipakai tebas rumput-rumput dan linggis dipakai untuk menggali akar tanaman liar, dan pengolahan lahan (balik tanah).

\section{b. Persiapan Bahan Tanaman}

Bahan tanaman yang digunakan adalah benih untuk komoditi jagung, kacang tanah dan kacang hijau, sedangkan ubi kayu menggunakan bahan tanaman berupa setek. Benih jagung, kacang tanah, dan kacang hijau yang digunakan oleh 
petani adalah benih yang disiapkan sejak dari panen pada musim tanam sebelumnya. Jagung yang dipanen pada tahun lalu kemudian disimpan di tempat penyimpanan (lumbung atau lopo) dalam bentuk $k$ 'butu (kumpulan beberapa bulir jagung yang diikat). Jagung kemudian diambil dari tempat penyimpanan dan dikupas kulitnya lalu dipipil, selanjutnya dipilih biji jagung yang baik untuk siap ditanam pada lahan yang sudah disiapkan, demikian juga dilakukan pada benih kacang tanah dan kacang hijau. Setek ubi kayu diambil dari batang ubi kayu yang masih tumbuh atau batang ubi kayu yang telah dipanen tetapi batangnya sengaja dikumpul dan ditumbuhkan untuk kemudian dijadikan setek pada musim tanam berikutnya.

\section{c. Penanaman}

Penanaman dilakukan pada awal musim hujan yaitu berkisar antara bulan November-Desember dengan semua jenis tanaman yang diusahakan ditanam dalam satu lahan yang sama. Kegiatan penanaman dilakukan secara tradisional, penanaman jagung dilakukan menggunakan linggis atau tugal (kayu runcing) untuk membuat lubang tanam dengan jarak tanam yang hanya diperkirakan +75 x $50 \mathrm{~cm}$. Setiap lubang tanam diisi 3-4 benih jagung dan biasa ditanam langsung bersamaan dengan kacang tali kemudian ditutup rapat dengan tanah. Kacang tanah, kacang hijau, dan ubi kayu ditanam di antara tanaman jagung. Penanaman ubi kayu menggunakan setek batang dengan setiap lubang terisi 2 setek.

\section{d. Penyiangan}

Penyiangan dilakukan oleh petani 1-3 kali dalam satu musim tanam, tergantung dari kondisi gulma. Penyiangan pada tanaman jagung dilakukan apabila tanaman sudah berumur 5-6 helai daun. Penyiangan pertama membutuhkan tenaga kerja cukup banyak karena biasanya dilakukan secara manual dengan menggunakan tofa (tajak) atau pacul dan dilakukan secara gotong royong. Penyiangan kedua dilakukan dengan penyemprotan menggunakan herbisida. Herbisida yang dipakai petani adalah Benzona yang dibeli saat sebelum musim hujan sehingga harganya tetap, dan herbisida yang digunakan bukan merupakan bantuan dari pihak lain tetapi dibeli sendiri oleh petani di Kefamenanu atau di pasar-pasar yang terdekat. Alat yang digunakan untuk penyemprotan adalah handsprayer. Penyiangan yang ketiga biasanya dilakukan secara manual seperti saat penyiangan pertama.

\section{e. Panen dan Pasca Panen}

Panen jagung dilakukan saat umur tanaman berkisar antara 3-4 bulan setelah tanam. Panen dilakukan apabila jagung sudah tua, berwarna kucing kecokelatan akibat mengering. Kegiatan panen di lokasi penelitian dilakukan dengan cara manual yakni bulir jagung dipatah kemudian dikumpulkan. Setelah panen, kegiatan pasca panen yang dilakukan adalah jagung dipisahkan antara bulir jagung yang besar dan bulir jagung yang kecil. Jagung yang kecil langsung dikupas kulitnya sedangkan jagung yang besar tidak dikupas. Jagung kemudian diangkut ke rumah petani dengan alat transportasi seperti motor/gerobak dan ada menggunakan mobil pickup. Selanjutnya jagung diikat dengan cara melipat ujung kulit jagung kemudian diikat dengan kulit jagung yang dibuat melingkar. Ikatan jagung terdiri dari beberapa jenis yakni 1) ikatan aisaf yang terdiri dari 6 puler yang diikat menjadi satu; 2) ikatan ani yang terdiri dari 6 aisaf yang diikat menjadi satu; 3) ikatan $k^{\prime} b u t u$ yang terdiri dari 12 ani yang diikat menjadi satu; dan 4) ikatan bikase atau kuda yang terdiri dari 24 ani yang diikat menjadi satu. Setelah diikat, jagung dijemur selama 2-3 hari kemudian disimpan pada tempat penyimpanan yakni dalam lopo atau lumbung.

Panen kacang tanah dan kacang hijau saat tanaman mulai mengering karena tua. Setelah panen kacang dijemur selama 2-3 hari. Panen ubi kayu tidak dilakukan secara serentak, panen hanya dilakukan sesuai kebutuhan misalnya panen saat akan dikonsumsi atau panen saat akan dijual.

\subsection{Analisis Pendapatan Usahatani Palawija}

\section{a. Penerimaan Usahatani}

Hasil yang diperoleh petani palawija di desa Letneo Selatan dan desa Unini digunakan untuk keperluan konsumsi dan sebagian dijual. Jumlah yang dikonsumsi, dijual, dan total produksi dari setiap komoditi dapat dilihat pada Tabel 1.

Tabel 1. Produksi Usahatani Palawija

\begin{tabular}{clcrrr}
\hline No & \multicolumn{1}{c}{ Komoditi } & Satuan & Konsumsi & \multicolumn{1}{c}{ Dijual } & Total Produksi \\
\hline 1 & Jagung Lokal Putih & $\mathrm{kg}$ & 7.950 & 10.875 & 18.825 \\
2 & Jagung Lokal Kuning & $\mathrm{kg}$ & 5.900 & 7.435 & 13.335 \\
3 & Kacang Tanah & $\mathrm{kg}$ & 505 & 655 & 1.160 \\
4 & Kacang Hijau & $\mathrm{kg}$ & 460 & 730 & 1.190 \\
5 & Ubi Kayu & Karung & 1.155 & 1.475 & 2.630 \\
\hline
\end{tabular}

Penerimaan merupakan perkalian antara produksi palawija yang diusahakan dengan harga jual masing-masing komoditi. Menurut Moy dkk., (2017) salah satu faktor yang menentukan keuntungan ekonomis suatu usahatani adalah jumlah produksi usahatani tersebut. Penerimaan usahatani palawija berupa jagung lokal putih, jagung lokal kuning, kacang tanah, kacang hijau, dan ubi kayu di desa Letneo Selatan dan desa Unini, kecamatan Insana Barat dapat dilihat pada Tabel 2 .

\begin{tabular}{llrrr}
\multicolumn{5}{l}{ Tabel 2. Penerimaan Usahatani Palawija } \\
\hline \multirow{2}{*}{ No } & \multicolumn{1}{c}{ Komoditi } & $\begin{array}{c}\text { Harga } \\
(\mathrm{Rp})\end{array}$ & $\begin{array}{c}\text { Total } \\
\text { Penerimaan }(\mathrm{Rp})\end{array}$ & $\begin{array}{c}\text { Rata-Rata } \\
\text { Penerimaan (Rp) }\end{array}$ \\
\hline 1 & Jagung Lokal Putih & $7.000,00$ & $76.125 .000,00$ & $2.537 .500,00$ \\
2 & Jagung Lokal Kuning & $7.000,00$ & $52.045 .000,00$ & $1.734 .833,00$ \\
3 & Kacang Tanah & $25.000,00$ & $16.375 .000,00$ & $545.833,00$ \\
4 & Kacang Hijau & $20.000,00$ & $14.600 .000,00$ & $486.667,00$ \\
5 & Ubi Kayu & $50.000,00$ & $73.750 .000,00$ & $2.458 .333,00$ \\
\hline \multicolumn{7}{l}{ Total } & & $232.895 .000,00$ & $7.763 .167,00$ \\
\hline
\end{tabular}

\section{b. Biaya Produksi}

Menurut Mubyarto, (1989) yang termasuk biaya produksi adalah semua pengorbanan yang dikeluarkan dan digunakan untuk menghasilkan sejumlah produksi tertentu. Biaya produksi yang dikeluarkan untuk usahatani palawija berupa biaya variabel (biaya benih, biaya pestisida, biaya konsumsi tenaga kerja, dan biaya tetap (penyusutan alat dan biaya pajak).

- Biaya Variabel

Berdasarkan hasil penelitian yang dilakukan, rata-rata biaya variabel yang dikeluarkan dalam satu kali proses produksi sebesar Rp1.039.500,00 dari total biaya sebesar Rp31.185.000,00. Biaya produksi tersebut terdiri dari beberapa jenis yakni 1) biaya benih jagung putih sebesar Rp160.000,00 dengan rata-rata Rp5.333,33, jagung kuning sebesar Rp155.000,00 dengan rata-rata Rp5.166,67, kacang hijau sebesar Rp1.060.000,00 dengan rata-rata Rp35.333,33, ubi kayu sebesar Rp2.270.000,00 dengan rata-rata Rp75.666,67, kacang tanah sebesar Rp1.400.000,00 dengan rata-rata Rp46.666,67; 2) biaya pestisida sebesar Rp11.960.000,00 dengan rata-rata Rp398.666,67; dan 3) biaya konsumsi tenaga kerja sebesar Rp14.180.000,00 dengan rata-rata Rp472.666,67.

- Biaya Tetap

Biaya tetap dalam penelitian ini meliputi biaya penyusutan alat dan pajak. Rata-rata biaya penyusutan alat yang dikeluarkan petani untuk usahatani palawija sebesar Rp66.854,17 dari total keseluruhan biaya yang dikeluarkan sebesar Rp2.005.625,00 dan biaya pajak sebesar Rp375.000,00 dengan rata-rata biaya Rp12.500,00 sehingga total biaya tetap untuk usahatani palawija sebesar Rp2.380.625,00 dengan rata-rata biaya Rp79.354,17.

Biaya tersebut terdiri dari penyusutan beberapa alat yakni 1) linggis dengan rata-rata biaya Rp1.916,67 dari total biaya sebesar Rp57.500,00; 2) parang dengan rata-rata biaya Rp2.458,33 dari total biaya sebesar Rp73.750,00; 3) tajak dengan rata-rata biaya Rp1.983,33 dari total biaya sebesar Rp59.500,00; 4) pacul dengan rata-rata biaya Rp1.645,83 dari total biaya sebesar Rp49.375,00; 5) terpal dengan rata-rata biaya Rp31.250,00 dari total biaya sebesar Rp937.500,00; 6) karung dengan rata-rata biaya sebesar $\mathrm{Rp27.600,00}$ dari total biaya Rp828.000,00; dan 7) pajak dengan rata-rata biaya sebesar Rp12.500,00 dari total biaya sebesar Rp375.000,00.

- Join Cost

Join cost dalam penelitian ini meliputi biaya penyusutan alat, biaya konsumsi tenaga kerja, pestisida dan biaya pajak yang total keseluruhan biaya dibagi lima karena total biaya digunakan untuk lima komoditi yaitu jagung putih, jagung kuning, kacang tanah, kacang hijau, dan ubi kayu. Berdasarkan hasil perhitungan diperoleh join cost untuk penyusutan alat sebesar Rp401.125,00 dari total keseluruhan biaya penyusutan sebesar Rp2.005.625,00. Join cost konsumsi tenaga kerja sebesar Rp2.836.000,00 dari total keseluruhan biaya sebesar Rp14.180.000,00. Join cost untuk pajak sebesar Rp75.000,00 dari total keseluruhan biaya sebesar Rp375.000,00. Join cost untuk pestisida sebesar Rp2.392.000,00 dari keseluruhan biaya sebesar Rp11.960.000,00.

\section{c. Pendapatan}

Pendapatan palawija diperoleh dari selisih penerimaan jagung lokal putih, jagung lokal kuning, kacang tanah, kacang hijau, dan ubi kayu dengan biaya yang dikeluarkan yang terdiri dari biaya tetap dan biaya variabel. Total biaya, total penerimaan, total pendapatan, dan pendapatan per petani dari usahatani palawija dapat dilihat pada Tabel 3 .

Tabel 3. Total Biaya, Total Penerimaan, Total Pendapatan, dan Pendapatan Per Petani dari Usahatani Palawija

\begin{tabular}{|c|c|c|c|c|}
\hline Komoditi & $\begin{array}{l}\text { Total Biaya } \\
\text { (Rp) }\end{array}$ & $\begin{array}{c}\text { Total } \\
\text { Penerimaan } \\
(\mathrm{Rp})\end{array}$ & $\begin{array}{c}\text { Total } \\
\text { Pendapatan } \\
\text { (Rp) }\end{array}$ & $\begin{array}{c}\text { Pendapatan Per } \\
\text { Petani (Rp) }\end{array}$ \\
\hline Jagung Lokal Putih & $5.864 .125,00$ & $76.125 .000,00$ & $70.260 .875,00$ & $2.342 .029,17$ \\
\hline Jagung Lokal Kuning & $5.859 .125,00$ & $52.045 .000,00$ & $46.185 .875,00$ & $1.539 .529,17$ \\
\hline Kacang Tanah & $7.104 .125,00$ & $16.375 .000,00$ & $9.270 .875,00$ & $309.029,17$ \\
\hline Kacang Hijau & $6.764 .125,00$ & $14.600 .000,00$ & $7.835 .875,00$ & $261.195,83$ \\
\hline Ubi Kayu & $7.974 .125,00$ & $73.750 .000,00$ & $65.775 .875,00$ & $2.192 .529,17$ \\
\hline Total & $33.565 .625,00$ & $232.895 .000,00$ & $199.329 .375,00$ & $6.644 .312,50$ \\
\hline
\end{tabular}

Pendapatan setiap petani yang tertinggi atau $35,2 \%$ berasal dari usahatani jagung lokal putih sedangkan yang terendah atau hanya 3,9\% yang berasal dari usahatani kacang hijau, padahal jika dilihat dari aspek biaya yang dikeluarkan oleh petani terlihat bahwa usahatani kacang hijau membutuhkan biaya lebih besar atau 20,2\% dari jagung lokal putih yang hanya membutuhkan $17,5 \%$ dari total biaya yang dikeluarkan oleh petani. 


\section{Simpulan}

Usahatani palawija di desa Letneo Selatan dan desa Unini, kecamatan Insana Barat dilakukan dengan pola tanam tumpangsari tanaman jagung lokal putih, jagung lokal kuning, kacang tanah, kacang hijau dan ubi kayu. Terdapat juga kacang tali yang tidak dianalisis dalam penelitian ini. Tahap-tahap usahatani yang dilakukan meliputi persiapan lahan, persiapan benih, penanaman, penyulaman, penyiangan atau penyemprotan pestisida, panen dan pasca panen. Selama melakukan usahatani, petani mengeluarkan total biaya sebesar Rp33.565.625,00 dengan rata-rata biaya $\mathrm{Rp} 1.118 .854,17$ yang terdiri dari biaya tetap dan biaya variabel. Total penerimaan usahatani palawija dalam satu kali musim tanam sebesar Rp232.895.000,00 dengan rata-rata penerimaan setiap petani sebesar Rp7.763.167,00 sehingga petani memperoleh total pendapatan Rp.199.329.375,00 dengan rata-rata pendapatan setiap petani sebesar Rp6.644.312,50 dengan perincian pendapatan dari jagung lokal putih sebesar Rp2.342.029,17, dari jagung lokal kuning sebesar Rp1.539.529,17, dari kacang tanah sebesar Rp309.029,17, dari kacang hijau sebesar Rp261.195,83, dan dari ubi kayu sebesar Rp2.192.529,17.

\section{Pustaka}

Ating, S. \& Sambas, A.M. 2006. Aplikasi Statistika Dalam Penelitian. Bandung: Penerbit Pustaka Setia.

Berek, A.K., Tabati, P.O., Keraf, U.U., Bere, E., Taekab, R. \& Wora, A. 2017. Perbaikan Pertumbuhan dan Hasil Kacang Tanah di Tanah Entisol Semiarid melalui Aplikasi Biochar. Savana Cendana, 2(03): 56-58.

Bhato, M.A. 2016. Respon Pertumbuhan dan Hasil Jagung (Zea mays L.) Varietas Pioner terhadap Berbagai Takaran Pupuk Kandang Babi dan Jarak Tanam. Savana Cendana, 1(02): 85-89.

Ceunfin, S., Humoen, M.U., Boyfala, S.M.A., Seran, A.H. \& Lelang, A. 2018 Pengaruh Model Defoliasi Daun Jagung dan Jumlah Benih terhadap Hasil Jagung dan Kacang Nasi pada Sistem Tumpangsari Salome (Kearifan Lokal Timor). Savana Cendana, 3(01): 8-10.

Ceunfin, S., Prajitno, D., Suryanto, P. \& Putra, E.T.S. 2017. Penilaian Kompetis dan Keuntungan Hasil Tumpangsari Jagung Kedelai di Bawah Tegakan Kayu Putih. Savana Cendana, 2(01): 1-3.

Falo, M. \& Fallo, Y.M. 2016. Kajian Pendapatan Agroindustri Tortila di Kecamatan Insana Barat Kabupaten Timor Tengah Utara. A GRIMOR, 1(02) 19-20.

Falo, M. \& Nubatonis, A. 2017. Partisipasi Anggota Kelompok Tani dalam Berusahatani Bawang Putih di Desa Sallu Kecamatan Miomaffo Barat Kabupaten Timor Tengah Utara. AGRIMOR, 2(02): 17-22.

Hadisapoetro, S. 1973. Pembangunan Pertanian. Yogyakarta: Departemen Ekonomi Pertanian Fakultas Pertanian, Universitas Gadjah Mada.

Haryanto, E. 2007. Sawi \& Selada. Revisi ed. Seri Agribisnis. Jakarta: Penebar Swadaya.

Karyawati, A.S., Waluyo, B. \& Basuki, N. 2010. Evaluasi Penampilan Plasma Nutfah Jagung dan Galur Kedelai Hasil Mutasi untuk Tumpangsari Menggunakan Ugmented Design. Skripsi. Malang: Universitas Brawijaya.

Manikin, E.T. \& Lelang, M.A. 2016. Pengaruh Model Penyimpanan Benih dan Jumlah Biji Per Lubang Tanam terhadap Pertumbuhan dan Hasil Jagung (Zea mays L.). Savana Cendana, 1(02): 54-58.

Moy, E., Fallo, Y.M. \& Falo, M. 2017. Faktor-Faktor yang Mempengaruhi Produksi Usahatani Kacang Hijau di Desa Tunabesi Kecamatan Io Kufeu Kabupaten Malaka. AGRIMOR, 2(04): 50-51.

Mubyarto 1989. Pengantar ekonomi pertanian. Jakarta: Lembaga Penelitian, Pendidikan dan Penerangan Ekonomi dan Sosial.

Nahak, M.H. \& Kune, S.J. 2017. Analisis Pendapatan Usahatani Jagung di Desa Bannae Kecamatan Insana Barat Kabupaten Timor Tengah Utara. AGRIMOR, 2(04): 55-56.

Neo, F.X. \& Ceunfin, S. 2018. Pengaruh Model Tumpangsari dan Pengaturan Jarak Tanam Kacang Nasi (Vigna angularis L.) Kultivar Lokal terhadap Pertumbuhan dan Hasil Tanaman Jagung (Zea mays L.). Savana Cendana, 3(01): 14-17.

Neonbeni, E.Y. \& Seran, A. 2017. Pengaruh Takaran Guano dan Konsentrasi Teh Kompos terhadap Pertumbuhan dan Hasil Kacang Hijau (Vigna radiata L.). Savana Cendana, 2(03): 42-45.

Soekartawi 1995. Analisis Usaha Tani. Jakarta: Universitas Indonesia Press.

Sugiyono, 2006. Metode Penelitian Kuantitatif, Kualitatif dan $R \& D$. Bandung: Alfabeta.

Suparman, 2007. Bercocok Tanam Ubi jalar. Jakarta: Azka Press.

Suratiyah, K. 2006. Ilmu Usahatani. Revisi ed. Jakarta: Penebar Swadaya.

Tetik, A.H. \& Fallo, Y.M. 2016. Analisis Pendapatan Usahatani Kacang Hijau di Kecamatan Wewiku Kabupaten Malaka. AGRIMOR, 1(03): 53-54.

Warsawa 2009. Introduksi Teknologi Tumpangsari Jagung dan Kacang Tanah. Tabloid Sinar Tani. 25 Feb. 